\title{
Sodium Channel Protein Type 5 Subunit Alpha
}

National Cancer Institute

\section{Source}

National Cancer Institute. Sodium Channel Protein Type 5 Subunit Alpha. NCI Thesaurus.

Code C131568.

Sodium channel protein type 5 subunit alpha (2016 aa, $\sim 227$ kDa) is encoded by the human SCN5A gene. This protein is involved in voltage-gated transport of sodium ions. 